\title{
CHEMOSPHERE
}

\section{PCDD/Fs levels in indoor environments and blood of workers of three municipal waste incinerators in Taiwan}

\author{
Suh-Woan $\mathrm{Hu}^{\text {a }}$, Guo-Ping ChangChien ${ }^{\mathrm{b}}$, Chang-Chuan Chan ${ }^{\mathrm{c}, *}$ \\ ${ }^{a}$ Institute of Stomatology, Chung Shan Medical University, 110 Sec. 1 Chien-Kuo N. Rd., Taichung 402, Taiwan \\ ${ }^{\mathrm{b}}$ Super Micro Mass Research and Technology Center, Cheng-Shiu Institute of Technology, \\ 840 Chengching Rd., Kaohsiung 833, Taiwan \\ ${ }^{\mathrm{c}}$ Institute of Occupational Medicine and Industrial Hygiene, College of Public Health, \\ National Taiwan University, Rm. 1447, No. 1, Sec. 1, Jen-ai Rd., Taipei, Taiwan
}

Received 7 January 2003; received in revised form 10 June 2003; accepted 24 October 2003

\begin{abstract}
This study monitored ambient air concentrations of polychlorinated dibenzo- $p$-dioxins and polychlorinated dibenzofurans (PCDD/Fs) in three municipal waste incineration plants. Blood PCDD/Fs levels of 133 workers randomly selected from these plants were also measured. The associations between workers' blood PCDD/Fs concentrations and occupational exposures to PCDD/Fs were assessed. Means of air PCDD/Fs levels ranged from 0.08 to $3.01 \mathrm{pg} / \mathrm{m}^{3}$ in international toxic equivalents (I-TEQ). The geometric means of blood PCDD/Fs concentrations were 14.6, 15.8, 19.1 $\mathrm{pg} / \mathrm{g}$ lipid in World Health Organization (WHO) TEQ, respectively, for workers from three plants. Air levels of total I-TEQ and all congeners, except 2,3,7,8-tetrachlorinated dibenzo-p-dioxin (TeCDD) and 1,2,3,4,7,8,9-heptachlorinated dibenzofuran (HpCDF), were significantly higher in plant B. However, blood concentrations of 2,3,7,8-TeCDD, 1,2,3,7,8-PeCDD, 2,3,7,8-TeCDF, 1,2,3,7,8-PeCDF and 1,2,3,4,7,8,9-HpCDF were significantly elevated in plant $\mathrm{C}$ workers. Although job contents, duration of employment and time spent in certain location were significantly different among incineration plants, they were not significantly associated with blood concentrations of any congener. Furthermore, results of the multiple regression analysis that assessed important occupational factors simultaneously and adjusted for potential confounders, showed significant associations between four congeners and incineration plant or job contents. However, the results were limited by small $R$-squares of the regression models. In conclusion, blood concentrations of several PCDD/Fs congeners were significantly different among three incineration plants. The differences were not explained by the discrepancy in job contents, duration of employment, and time activity in these plants.
\end{abstract}

(c) 2003 Elsevier Ltd. All rights reserved.

Keywords: Polychlorinated dibenzo-p-dioxins; Polychlorinated dibenzofurans; Occupational exposure; Waste incineration

\section{Introduction}

Until recent years, waste incineration has been one of the main sources for polychlorinated dibenzo-p-dioxins

\footnotetext{
${ }^{*}$ Corresponding author. Tel./fax: +886-2-23222362.

E-mail address: ccchan@ha.mc.ntu.edu.tw (C.-C. Chan).
}

and polychlorinated dibenzofurans (PCDD/Fs) (McGregor et al., 1998). Several studies have investigated PCDD/Fs exposure in municipal or hazardous waste incinerator workers. The results showed that workers of municipal waste incinerators had significantly higher lipid-based blood levels of total PCDD/Fs and hexa-chlorinated dibenzofurans (CDF) (Schecter et al., 1991; Schecter et al., 1995), and 1,2,3,4,6,7,8-HpCDF (Kumagai et al., 2000; Kumagai et al., 2002) compared 
to controls. Another study found higher levels of international toxic equivalents (I-TEQ) for PCDD/Fs in workers of an industrial waste incineration plant than in controls (Kim et al., 2001). Nineteen large-scale municipal waste incineration plants are currently operating in Taiwan, with two more under construction. Nonetheless, the ambient PCDD/Fs levels in waste incineration plants and their relationship with the blood PCDD/Fs concentrations in incinerator workers have not been investigated in Taiwan. The purposes of this investigation were to monitor ambient air PCDD/Fs concentrations of three municipal waste incineration plants, to measure blood PCDD/Fs levels in workers from these plants, and to assess the associations between workers' blood PCDD/Fs concentrations and occupational exposure to these compounds in these three plants.

\section{Materials and methods}

\subsection{Study incineration plants}

The three municipal solid waste incineration plants, A, B and C, were located in northern Taiwan and have been operating since 1991, 1998, and 1994, respectively. Plant A has three incinerator units and burns about 140000 tons of waste per year at a minimal temperature of $850^{\circ} \mathrm{C}$. It has been equipped with semi-dry scrubbers, activated carbon injection, and bag filter since the year of 2000 (wet scrubber and electrostatic precipitator before 2000) and fly ash solidification facility. Plant B consists of four incinerator units and handles about 410000 tons of waste per year at a minimal temperature of $850{ }^{\circ} \mathrm{C}$. This plant uses semi-dry scrubber and bag filter to treat flue gas. Plant $\mathrm{C}$ has four incinerator units, burns about 230000 tons of waste per year at $850-1050{ }^{\circ} \mathrm{C}$, and is equipped with electrostatic precipitator and wet scrubber.

\subsection{Study subjects}

Male workers employed more than 6 months in plants A, B or C were eligible for the study. Forty-five workers were randomly sampled from plants A and B, respectively. Forty-three workers were randomly selected from plant C. One worker absent on the first day of study was replaced with another worker from the same job category. Informed consent was obtained from each of the 133 participating workers.

We conducted a questionnaire survey to collect information regarding each participant's occupational history, smoking habits, food frequency, and demographics by using personal interviews for 114 workers and self-reporting for another 19 workers who insisted on answering the questionnaire by themselves.
In order to better understand each worker's occupational exposure in each plant, we conducted another interview survey for the worker's job activities. The workers were asked to describe the activities and time spent in each site during the eight working hours on the workday before.

\subsection{Air sampling and PCDD/Fs concentrations}

For each plant, ambient air samples were collected in four sites for a 3-day period. The four sites were: fly ash solidification facility, slag bunker, slag conveyor, and ash conveyor in plant A; ash conveyor, ash bunker, common fly ash conveyor, and ash moistening conveyor in plant B; ash conveyor, slag bunker, fly ash dumping station, and fly ash conveyor in plant C. In total, there were 12 air samples and three field blanks.

Samples were collected and analyzed in accordance with the revised EPA Reference Method TO 9A (US EPA, 1999) by the Super Micro Mass Research and Technology Center of the Cheng Shiu Institute of Technology in Taiwan. The General Metal Works Model PS-1 polyurethane foam (PUF) samplers with a flow rate about $0.225 \mathrm{~m}^{3} / \mathrm{min}$ were used to collect ambient air. Air samples of about $900 \mathrm{~m}^{3}$ were taken during the $72-\mathrm{h}$ period. The nominally defined particulate fraction was trapped on a quartz-fiber filter and the vapor-phase fraction was trapped on a PUF plug. The filter and PUF were combined for sample preparation, spiked with nine ${ }^{13} \mathrm{C}_{12}$-labeled PCDD/Fs internal standards, and Soxhlet extracted for $16 \mathrm{~h}$. The extract was subjected to a $\mathrm{H}_{2} \mathrm{SO}_{4}$ washing procedure followed by clean-up on columns of silica gel, alumina, and carbon. The elution was concentrated to approximately $1 \mathrm{ml}$ and transferred to a vial. The concentrate was further concentrated to near dryness, using a stream of nitrogen. Immediately prior to analysis, the standard solution for recovery checking was added to the sample. PCDD/Fs was measured by high-resolution gas chromatography (HRGC), a Hewlett Packard 6970 Series gas chromatograph equipped with a DB-5MS (J\&W Scientific, CA, USA), coupled with a high-resolution mass spectrometer (HRMS), a Micromass Autospec Ultima (UK) mass spectrometer with a positive electron impact $\left(\mathrm{EI}^{+}\right)$ source. Fused silica capillary column $(60 \mathrm{~m}, 0.25 \mathrm{~mm}$ ID, $0.25 \mu \mathrm{m}$ film thickness), splitless injection, and an initial oven temperature of $150{ }^{\circ} \mathrm{C}$ was used. The temperature was programmed as follows: $150{ }^{\circ} \mathrm{C}$ held for 1 min, increasing at $8{ }^{\circ} \mathrm{C} / \mathrm{min}$ to $220^{\circ} \mathrm{C}$, increasing at 1.5 ${ }^{\circ} \mathrm{C} / \mathrm{min}$ to $260^{\circ} \mathrm{C}$, and then increasing at $4{ }^{\circ} \mathrm{C} / \mathrm{min}$ to 310 ${ }^{\circ} \mathrm{C}$, and held for $5 \mathrm{~min}$ (total run $56.92 \mathrm{~min}$ ). Helium was used as the carrier gas. The valley value defined as 2,3,7,8-tetrachlorinated dibenzo- $p$-dioxin (TeCDD) smaller than $25 \%$ was required. Day check verification using the 1613CS3 standard solution was performed every $12 \mathrm{~h}$. The analyzer mode was selected ion moni- 
toring (SIM) at a resolution of 10000 . The electron energy was set at $35 \mathrm{eV}$, and the source temperature was set at $250^{\circ} \mathrm{C}$. The international toxic equivalency factors were used to calculate I-TEQ of total PCDD/Fs for each air sample.

\subsection{Blood PCDD/Fs concentrations}

Blood samples from 75 workers were analyzed at the ERGO Forschungsgesellschaft laboratory, a World Health Organization (WHO) certified laboratory, and 58 samples were analyzed at the Super Micro Mass Research and Technology Center of the Cheng-Shiu Institute of Technology in Taiwan. Blood samples were randomly assigned to these laboratories. Analytical personnel in both laboratories were not informed of the blood sample's identity and the worker's occupational exposure history.

Forty milliliter of each whole blood sample was analyzed to determine lipid-based dioxin levels by an isotope dilution method similar to the US EPA Method 1613 Revision B (US EPA, 1994). The analytical procedures have been described in details previously $(\mathrm{Hu}$ et al., 2003). The WHO toxic equivalency factors (Van den Berg et al., 1998) were used to derive WHO toxic equivalents (WHO-TEQ) of total PCDD/Fs for each sample. For blood samples with specific dioxin or furan levels lower than the limits of detection (LODs), their values were substituted by LODs/square root of 2 (Hornung and Reed, 1990). Furthermore, both laboratories analyzed four pairs of randomly selected blood samples in order to assure inter-laboratory consistency in PCDD/Fs analysis. The mean coefficients of variation for these four paired blood samples were $3.8 \%$ for total PCDDs, $29.9 \%$ for total PCDFs, and $31.1 \%$ for WHOTEQ.

\subsection{Data analysis}

The data analysis started with descriptive statistics of all important variables. Natural logarithm transformation was used to enhance normality for blood PCDD/Fs. Kruskal-Wallis test or one-way analysis of variance was conducted to compare means of continuous variables among three plants or among job groups. Chi-square test was used to compare frequencies of categorical variables. Spearman correlation coefficient was used to assess the correlation between blood levels of each congener and other continuous variables. We further compared blood levels of 2,3,7,8-TeCDD, four congeners, and WHO-TEQ among five job groups in each plant. These four congeners were 1,2,3,4,6,7,8-HpCDD, OCDD, OCDF, which were the indicatory PCDD/Fs of municipal waste incinerators in Taiwan (from our analysis of 130 samples of PCDD/Fs in flue gas from 13 large municipal waste incinerators), and 1,2,3,4,6,7,8-
$\mathrm{HpCDF}$ found to be elevated in incinerator workers (Kumagai et al., 2000). Finally, multiple linear regression analysis was applied to assess the associations between blood level of each congener and incineration plant (A, B or C), duration of employment and job contents simultaneously, controlling for potential confounders. The statistical software SAS version 8 (SAS Institute Inc., NC, USA) was applied for the analyses. A probability level of less than 0.05 was considered as significant.

\section{Results}

The air PCDD/Fs concentrations in three incineration plants are presented in Table 1. Mean levels of total PCDD/Fs, I-TEQ values and concentrations of all congeners (except 2,3,7,8-TeCDD and 1,2,3,4,7,8,9$\mathrm{HpCDF}$ ) were significantly higher in plant $\mathrm{B}$. The average I-TEQ of plant B $\left(3.01 \mathrm{pg} / \mathrm{m}^{3}\right)$ was 38 and 10 times higher than those of plants $\mathrm{A}\left(0.08 \mathrm{pg} / \mathrm{m}^{3}\right)$ and $\mathrm{C}$ $\left(0.31 \mathrm{pg} / \mathrm{m}^{3}\right)$, respectively. The highest concentration (7.11 $\mathrm{pg} / \mathrm{m}^{3}$ ) was detected in an air sample collected from the ash bunker of plant $B$.

Characteristics of study subjects are presented in Table 2. Duration of employment, frequencies of job contents, and frequency for milk consumption differed significantly among plants. Table 3 describes the blood PCDD/Fs concentrations of participating workers. The WHO-TEQ ranged from 5.5 to $59.0 \mathrm{pg} / \mathrm{g}$ lipid, with an arithmetic mean (standard deviation, SD) of 19.6 (12.4) $\mathrm{pg} / \mathrm{g}$ lipid for all workers.

Fig. 1 displays the contribution of each congener to WHO-TEQ in blood and I-TEQ in air, respectively. For all three plants, the two major congeners contributing to total TEQ were 1,2,3,7,8-PeCDD and 2,3,4,7,8-PeCDF in blood, and 2,3,4,7,8-PeCDF and 1,2,3,4,6,7,8-HpCDD in ambient air, respectively.

The time activity profiles of 133 workers are shown in Table 4. Workers from plant A spent significantly more time in the incinerator area than did plants $\mathrm{B}$ and $\mathrm{C}$ workers. Plant B workers had more time in the refuse weighing bridge area than did workers of plants A or C.

Regarding the relationship between blood PCDD/ Fs and important continuous variables, duration of employment was not significantly correlated with blood levels of any of the 17 congeners (Spearman correlation coefficients: -0.12 to 0.16 ). The Spearman correlation coefficients for time spent in each of the locations and blood levels of specific congeners were also small $(-0.21$ to 0.15 ).

Fig. 2 presents the mean (with standard error bars) blood concentrations of TCDD, 1,2,3,4,6,7,8-HpCDD, OCDD, OCDF, 1,2,3,4,6,7,8-HpCDF, and WHO-TEQ for workers with different job contents in each plant. 
Table 1

Air PCDD/Fs concentrations $\left(\mathrm{pg} / \mathrm{m}^{3}\right)$ in three incineration plants, results of three-day workplace air monitoring

\begin{tabular}{|c|c|c|c|c|c|c|}
\hline \multirow[t]{2}{*}{$\mathrm{PCDD} / \mathrm{Fs}$} & \multicolumn{2}{|c|}{ Plant A ( $n=4$ sites $)$} & \multicolumn{2}{|c|}{ Plant B ( $n=4$ sites $)$} & \multicolumn{2}{|c|}{ Plant C $(n=4$ sites $)$} \\
\hline & Mean (SD) & Range & Mean (SD) & Range & Mean (SD) & Range \\
\hline $2,3,7,8-\mathrm{TeCDD}$ & n.d. ${ }^{a}$ & n.d. & $0.22(0.23)$ & n.d. -0.53 & n.d. & n.d. \\
\hline 1,2,3,7,8-PeCDD & $0.02(0.01)^{*}$ & $0.01-0.03$ & $0.55(0.55)$ & $0.06-1.33$ & $0.02(0.02)$ & n.d. -0.03 \\
\hline $1,2,3,4,7,8-\mathrm{HxCDD}$ & $0.02(0.00)^{*}$ & $0.01-0.02$ & $0.52(0.50)$ & $0.06-1.24$ & $0.06(0.02)$ & $0.04-0.08$ \\
\hline 1,2,3,6,7,8-HxCDD & $0.04(0.01)^{*}$ & $0.02-0.05$ & $0.90(0.83)$ & $0.12-2.08$ & $0.26(0.14)$ & $0.12-0.44$ \\
\hline $1,2,3,7,8,9-\mathrm{HxCDD}$ & $0.03(0.01)^{*}$ & $0.02-0.04$ & $0.74(0.70)$ & $0.10-1.73$ & $0.16(0.09)$ & $0.08-0.28$ \\
\hline $1,2,3,4,6,7,8-\mathrm{HpCDD}$ & $0.18(0.06)^{*}$ & $0.12-0.24$ & $6.71(6.30)$ & $0.68-15.54$ & $3.13(2.64)$ & $0.96-6.97$ \\
\hline OCDD & $0.39(0.19)^{*}$ & $0.16-0.62$ & $20.41(19.29)$ & $1.60-47.33$ & $7.85(7.85)$ & $2.07-19.43$ \\
\hline $2,3,7,8-\mathrm{TeCDF}$ & $0.03(0.01)^{*}$ & $0.02-0.05$ & $1.07(1.04)$ & $0.13-2.54$ & $0.05(0.02)$ & $0.03-0.07$ \\
\hline $1,2,3,7,8-\mathrm{PeCDF}$ & $0.04(0.02)^{* *}$ & $0.03-0.06$ & $1.72(1.71)$ & $0.18-4.15$ & $0.08(0.02)$ & $0.06-0.10$ \\
\hline $2,3,4,7,8-\mathrm{PeCDF}$ & $0.06(0.03)^{* *}$ & $0.05-0.11$ & $2.15(2.08)$ & $0.26-5.11$ & $0.17(0.04)$ & $0.13-0.22$ \\
\hline $1,2,3,4,7,8-\mathrm{HxCDF}$ & $0.06(0.02)^{* *}$ & $0.04-0.09$ & $1.96(1.84)$ & $0.28-4.57$ & $0.15(0.04)$ & $0.12-0.20$ \\
\hline $1,2,3,6,7,8-\mathrm{HxCDF}$ & $0.06(0.03)^{* *}$ & $0.04-0.10$ & $2.25(2.16)$ & $0.26-5.32$ & $0.21(0.07)$ & $0.14-0.31$ \\
\hline $1,2,3,7,8,9-\mathrm{HxCDF}$ & $0.03(0.01)^{*}$ & $0.02-0.04$ & $1.06(1.00)$ & $0.13-2.48$ & $0.13(0.06)$ & $0.08-0.22$ \\
\hline $2,3,4,6,7,8-\mathrm{HxCDF}$ & $0.10(0.03)^{*}$ & $0.07-0.13$ & $3.12(2.92)$ & $0.38-7.23$ & $0.56(0.33)$ & $0.28-1.02$ \\
\hline $1,2,3,4,6,7,8-\mathrm{HpCDF}$ & $0.25(0.11)^{*}$ & $0.12-0.35$ & $7.30(6.59)$ & $1.11-16.59$ & $1.45(0.92)$ & $0.72-2.79$ \\
\hline $1,2,3,4,7,8,9-\mathrm{HpCDF}$ & $0.05(0.02)$ & $0.03-0.07$ & $1.81(1.80)$ & $0.00-4.30$ & $0.32(0.23)$ & $0.14-0.65$ \\
\hline OCDF & $0.20(0.12)^{*}$ & $0.08-0.36$ & $6.81(5.97)$ & $1.01-15.13$ & $1.78(1.55)$ & $0.68-4.07$ \\
\hline Total PCDD & $0.67(0.25)^{*}$ & $0.36-0.96$ & $29.84(28.16)$ & $2.63-69.26$ & $11.47(10.69)$ & $3.29-27.20$ \\
\hline Total PCDF & $0.88(0.32)^{*}$ & $0.51-1.16$ & $29.25(27.10)$ & $3.74-67.41$ & $4.90(3.18)$ & $2.42-9.54$ \\
\hline Total PCDD/PCDF & $1.55(0.55)^{*}$ & $0.87-2.09$ & $59.09(55.26)$ & $6.37-136.67$ & $16.37(13.85)$ & $5.71-36.74$ \\
\hline I-TEQ $\left(\mathrm{pg} / \mathrm{m}^{3}\right)$ & $0.08(0.03)^{*}$ & $0.06-0.13$ & $3.01(2.90)$ & $0.34-7.11$ & $0.31(0.12)$ & $0.20-0.48$ \\
\hline
\end{tabular}

${ }^{*}$ Significant differences at $p<0.05 ;{ }^{* *} p<0.01$, Kruskal-Wallis test for comparing mean air PCDD/Fs concentrations among three incinerator plants.

${ }^{\text {a }}$ Not detectable. 
Table 2

Characteristics of participating workers

\begin{tabular}{|c|c|c|c|}
\hline \multirow[t]{2}{*}{ Variables } & \multicolumn{3}{|c|}{ Workers categorized by plant } \\
\hline & Plant A & Plant B & Plant $\mathrm{C}$ \\
\hline$n$ & 45 & 45 & 43 \\
\hline Age, year ${ }^{\mathrm{a}}$ & $39.9(5.9)$ & $38.5(7.7)$ & $41.9(8.1)$ \\
\hline Duration of employment, year ${ }^{\mathrm{a}}$ & $7.2(3.3)^{b}$ & $2.6(0.9)$ & $5.1(2.4)$ \\
\hline Previous job at an incineration plant, $\%$ & 4.4 & 13.3 & 2.3 \\
\hline \multicolumn{4}{|l|}{ Job contents, $\%$} \\
\hline Ash/slag handling & $13.3^{\mathrm{c}}$ & 17.8 & 27.9 \\
\hline Central control of incineration & 22.2 & 33.3 & 25.6 \\
\hline Refuse handling only & 8.9 & 13.3 & 0 \\
\hline Maintenance & 40.0 & 20.0 & 14.0 \\
\hline Management & 15.6 & 15.6 & 32.6 \\
\hline \multicolumn{4}{|l|}{ Cigarette smoking status, $\%$} \\
\hline Current smoker & 37.8 & 40.0 & 41.9 \\
\hline Former smoker & 8.9 & 2.2 & 16.3 \\
\hline Never & 53.3 & 57.8 & 41.9 \\
\hline Body mass index, $\mathrm{kg} / \mathrm{m}^{2 \mathrm{a}}$ & $25.1(4.3)$ & $24.6(3.9)$ & $24.4(3.2)$ \\
\hline Fish consumption, meals/month ${ }^{\mathrm{a}}$ & $17.6(12.2)$ & $21.2(18.0)$ & $20.8(17.5)$ \\
\hline Meat consumption, meals/month ${ }^{\mathrm{a}}$ & $29.5(20.7)$ & $40.2(31.2)$ & $32.4(20.7)$ \\
\hline Milk consumption, meals/month ${ }^{\mathrm{a}}$ & $20.6(17.4)^{\mathrm{d}}$ & $28.2(16.2)$ & $30.8(12.1)$ \\
\hline $\begin{array}{l}{ }^{\mathrm{a}} \text { Mean (standard deviation). } \\
{ }_{p}{ }_{p}<0.001 \text {, analysis of variance, plants A } \\
{ }^{c} p<0.05 \text {, chi-square test. } \\
{ }^{\mathrm{d}} p<0.01 \text {, Kruskal-Wallis test. }\end{array}$ & & & \\
\hline
\end{tabular}

Although mean levels of TCDD, 1,2,3,4,6,7,8-HpCDD, OCDD, OCDF, and 1,2,3,4,6,7,8-HpCDF, respectively, were not significantly different among job groups, plants $\mathrm{B}$ and $\mathrm{C}$ workers, who handled ash, appeared to have higher blood levels of 1,2,3,4,6,7,8-HpCDD, OCDD, $1,2,3,4,6,7,8-\mathrm{HpCDF}$, and OCDF. Moreover, blood concentrations of the other 12 congeners were not significantly different among job groups.

Finally, we simultaneously assessed the associations between blood concentrations of each congener and incineration plant (A, B or C), duration of employment and job contents, controlling for potential confounding factors (age, body mass index, frequency of milk consumption, and current smoking status) in the multiple regression analysis. Incineration plant was significantly associated with blood concentrations of 1,2,3,7,8PeCDD, 2,3,7,8-TeCDF, and 1,2,3,7,8-PeCDF, respectively, the result was consistent with that from the unadjusted comparisons of these three congeners. Job content was associated with $1,2,3,4,6,7,8-\mathrm{HpCDF}$ and total PCDF, which were significantly elevated in workers handling ash compared to those doing managerial job. Duration of employment was not significantly related to any congener, nor was there a trend for higher blood PCDD/Fs with longer employment. $R$-squares for the regression models ranged from 0.05 to 0.24 . Variables included in the model explained only a small percentage of the variation in blood levels of respective congener.

\section{Discussion}

This study measured the concentrations of PCDD/Fs in 133 workers' blood and in workplace atmosphere of three municipal waste incineration plants in Taiwan. Means of air PCDD/Fs ranged from 0.08 to $3.01 \mathrm{pg}$ $\mathrm{I}-\mathrm{TEQ} / \mathrm{m}^{3}$, and concentrations of almost all congeners were significantly higher in plant B. Blood PCDD/Fs levels averaged 14.6-19.1 pg WHO-TEQ/g lipid in workers from the three plants. The concentrations of 2,3,7,8-TeCDD, 1,2,3,7,8-PeCDD, 2,3,7,8-TeCDF, 1,2,3, 7,8-PeCDF, and 1,2,3,4,7,8,9-HpCDF were significantly higher in plant $\mathrm{C}$ workers. We further investigated other occupational factors associated with blood $\mathrm{PCDD} / \mathrm{Fs}$ concentrations. Although time spent in certain locations, job contents and duration of employment were significantly different among incineration plants, they were not significantly associated with blood concentrations of any congener. These factors were not likely to account for the differences in blood PCDD/Fs among plants. Furthermore, results of the multiple regression analyses for blood levels of each congener were limited by small $R$-squares. However, incineration plant and job contents appeared to be significantly associated with blood levels of several congeners in the regression models.

Other possible reasons for the differences in blood levels of several congeners among plants could be the following. The time activity data revealed that most 
Table 3

Blood dioxins and furans concentrations (pg/g, lipid based) in all 133 workers and categorized by plant

\begin{tabular}{|c|c|c|c|c|c|}
\hline \multirow[t]{2}{*}{$\mathrm{PCDD} / \mathrm{Fs}$} & \multicolumn{2}{|c|}{ All workers } & \multicolumn{3}{|c|}{ Geometric mean (SD) for each plant } \\
\hline & Median & Range & Plant A & Plant B & Plant C \\
\hline 2,3,7,8-TeCDD & 1.6 & n.d. ${ }^{\mathrm{a}}-14$ & $1.6(3.0)^{* *} \mathrm{C}>\mathrm{A}, \mathrm{B}$ & $1.5(2.5)$ & $2.9(2.4)$ \\
\hline $1,2,3,7,8-\mathrm{PeCDD}$ & 4.2 & n.d. -24.9 & $2.9(4.4)^{*} \mathrm{C}>\mathrm{A}$ & $3.1(2.2)$ & $5.4(2.5)$ \\
\hline $1,2,3,4,7,8-\mathrm{HxCDD}$ & 2.5 & n.d. -12.6 & $2.6(2.8)$ & $2.1(2.6)$ & $3.0(2.3)$ \\
\hline $1,2,3,6,7,8-\mathrm{HxCDD}$ & 20.3 & $4.9-74.5$ & $20.8(1.9)$ & $17.3(2.1)$ & $21.6(2.2)$ \\
\hline $1,2,3,7,8,9-\mathrm{HxCDD}$ & 3.9 & n.d. -38.4 & $5.0(2.9)$ & $4.6(3.1)$ & $5.8(2.9)$ \\
\hline $1,2,3,4,6,7,8-\mathrm{HpCDD}$ & 36.9 & n.d. -206.1 & $32.0(2.2)$ & $28.8(2.3)$ & $32.5(2.3)$ \\
\hline OCDD & 330.0 & $65.8-1754.7$ & $315.0(1.9)$ & $313.2(1.8)$ & $355.3(1.9)$ \\
\hline $2,3,7,8-\mathrm{TeCDF}$ & 1.3 & n.d. -14.9 & $0.5(3.8)^{* * *} \mathrm{C}, \mathrm{B}>\mathrm{A}$ & $1.3(2.1)$ & $1.8(2.9)$ \\
\hline $1,2,3,7,8-\mathrm{PeCDF}$ & 0.7 & n.d. -13.9 & $0.4(4.5)^{* * *} \mathrm{C}>\mathrm{A}$ & $0.7(2.8)$ & $1.3(3.3)$ \\
\hline $2,3,4,7,8-\mathrm{PeCDF}$ & 7.5 & n.d. -46.9 & $7.4(1.6)$ & $6.6(2.2)$ & $8.6(2.0)$ \\
\hline $1,2,3,4,7,8-\mathrm{HxCDF}$ & 5.2 & n.d. -23.9 & $5.6(1.5)$ & $4.6(2.1)$ & $4.5(1.9)$ \\
\hline $1,2,3,6,7,8-\mathrm{HxCDF}$ & 4.2 & n.d. -24.1 & $4.8(1.6)$ & $4.0(1.8)$ & $4.0(2.1)$ \\
\hline $1,2,3,7,8,9-\mathrm{HxCDF}$ & 1.8 & n.d. -26.1 & $1.3(4.3)$ & $1.1(6.6)$ & $2.6(3.7)$ \\
\hline $2,3,4,6,7,8-\mathrm{HxCDF}$ & 1.8 & n.d. -97.6 & $2.1(2.4)$ & $2.3(2.7)$ & $2.4(2.5)$ \\
\hline $1,2,3,4,6,7,8-\mathrm{HpCDF}$ & 12.2 & n.d. -343.8 & $12.1(1.9)$ & $10.6(3.0)$ & $11.8(2.0)$ \\
\hline $1,2,3,4,7,8,9-\mathrm{HpCDF}$ & 2.1 & n.d. -63.1 & $0.9(4.9)^{*} \mathrm{C}>\mathrm{B}$ & $0.7(6.8)$ & $1.7(3.9)$ \\
\hline OCDF & 13.3 & n.d. -605.6 & $14.9(1.6)^{*} \mathrm{~B}>\mathrm{C}$ & $17.6(2.3)$ & $11.4(2.0)$ \\
\hline Total PCDD & 417.5 & $81.4-1890.1$ & $401.6(1.8)$ & $387.4(1.7)$ & $444.2(1.8)$ \\
\hline Total PCDF & 54.1 & $23.5-1202.2$ & $56.7(1.4)$ & 60.5 & $54.1(1.7)$ \\
\hline Total PCDD/PCDF & 479.0 & $107.5-2280.0$ & $465.3(1.7)$ & $457.3(1.7)$ & $505.5(1.8)$ \\
\hline WHO-TEQ & 15.3 & $5.5-59.0$ & $15.8(1.7)$ & $14.6(1.8)$ & $19.1(2.0)$ \\
\hline
\end{tabular}

${ }^{*}$ Significant differences at $p<0.05,{ }^{* *} p<0.01,{ }^{* * *} p<0.001$, one-way analysis of variance on a natural log-transformed scale

${ }^{a}$ For those blood samples with non-detectable value for a specific dioxin or furan, the detection limit of the specific congener divided by the square root of 2 was used in the calculation of mean and standard deviation of blood dioxins and furans for all workers. 

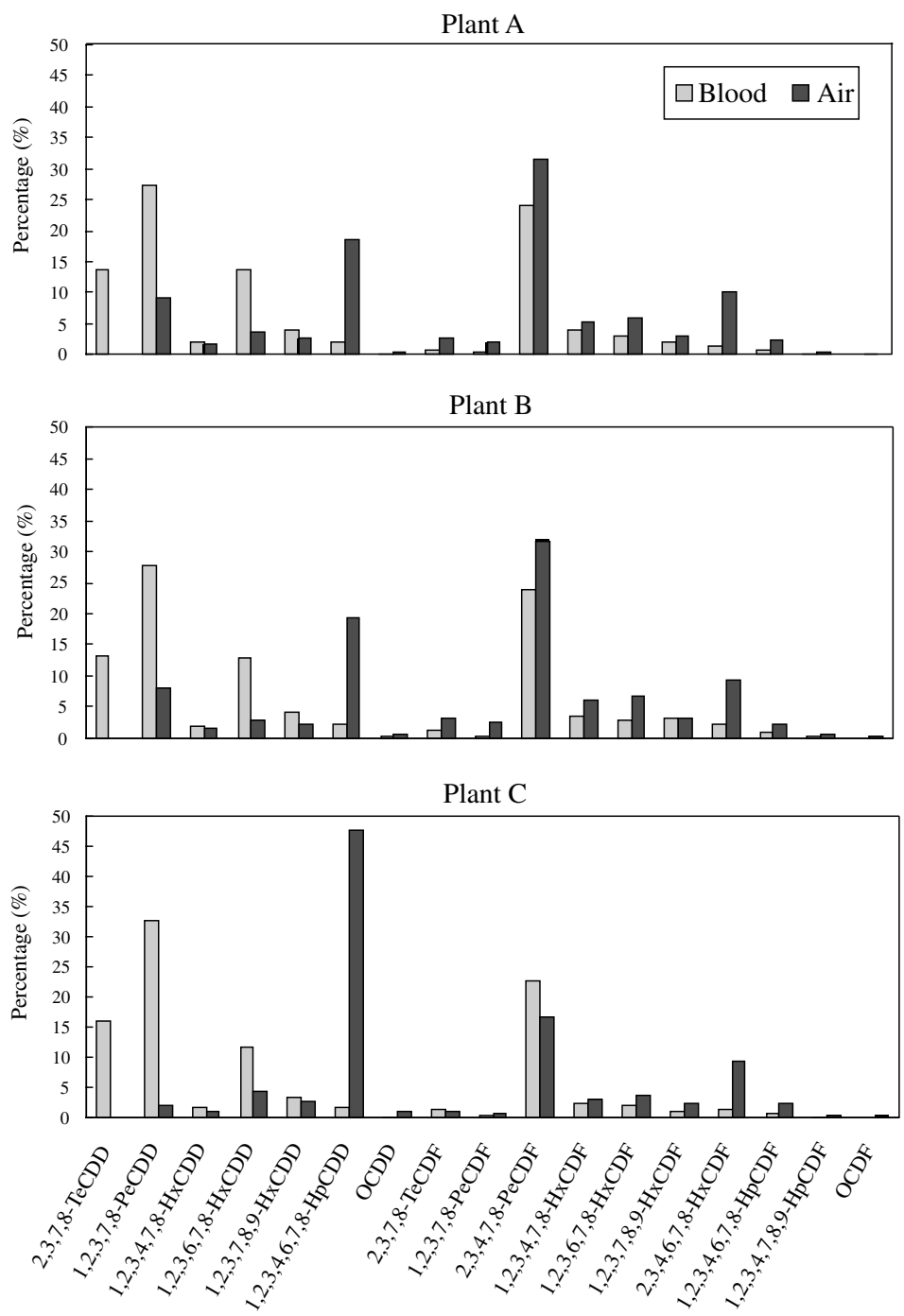

Fig. 1. Contribution of each congener to I-TEQ in the air and WHO-TEQ in the blood samples of three municipal waste incinerators.

Table 4

Time activity profile of 133 workers-hours spent in each location during an 8-h workday

\begin{tabular}{lcccc}
\hline Location & All workers & \multicolumn{2}{l}{ Categorized by plant } & \\
\cline { 3 - 4 } & & Plant A & Plant B & Plant C \\
\hline$n$ & 133 & 45 & 45 & 43 \\
Ash crane operating room & $0.5(1.3)^{\mathrm{a}}$ & $0.3(1.0)$ & $0.7(1.5)$ & $0.6(1.4)$ \\
Central control room & $1.2(2.3)$ & $0.7(1.7)$ & $1.3(2.3)$ & $1.8(2.7)$ \\
Incinerator area & $2.2(2.1)$ & $3.0(2.2)^{*}$ & $2.0(2.0)$ & $1.7(1.9)$ \\
Office & $2.3(2.7)$ & $2.6(2.3)$ & $1.8(2.4)$ & $2.3(3.2)$ \\
Refuse crane operating room & $0.4(1.2)$ & $0.3(1.0)$ & $0.4(1.2)$ & $0.6(1.4)$ \\
Refuse dumping station & $0.3(1.1)$ & $0.6(1.8)$ & $0.2(0.6)$ & $0.1(0.4)$ \\
Refuse weighing bridge & $0.3(1.5)$ & $0.1(0.4)^{*}$ & $0.9(2.5)$ & 0 \\
Wastewater treatment facility & $0.1(0.7)$ & $0.2(0.6)$ & $0.2(1.0)$ & $0.01(0.1)$ \\
Other areas & $0.7(2.0)$ & $0.4(1.5)$ & $0.7(2.0)$ & $1.0(2.5)$ \\
\hline
\end{tabular}

*Significant differences at $p<0.05$, Kruskal-Wallis test for comparisons among three plants.

${ }^{\mathrm{a}}$ Mean (standard deviation) of hours spent in each location during an 8-h working day. 

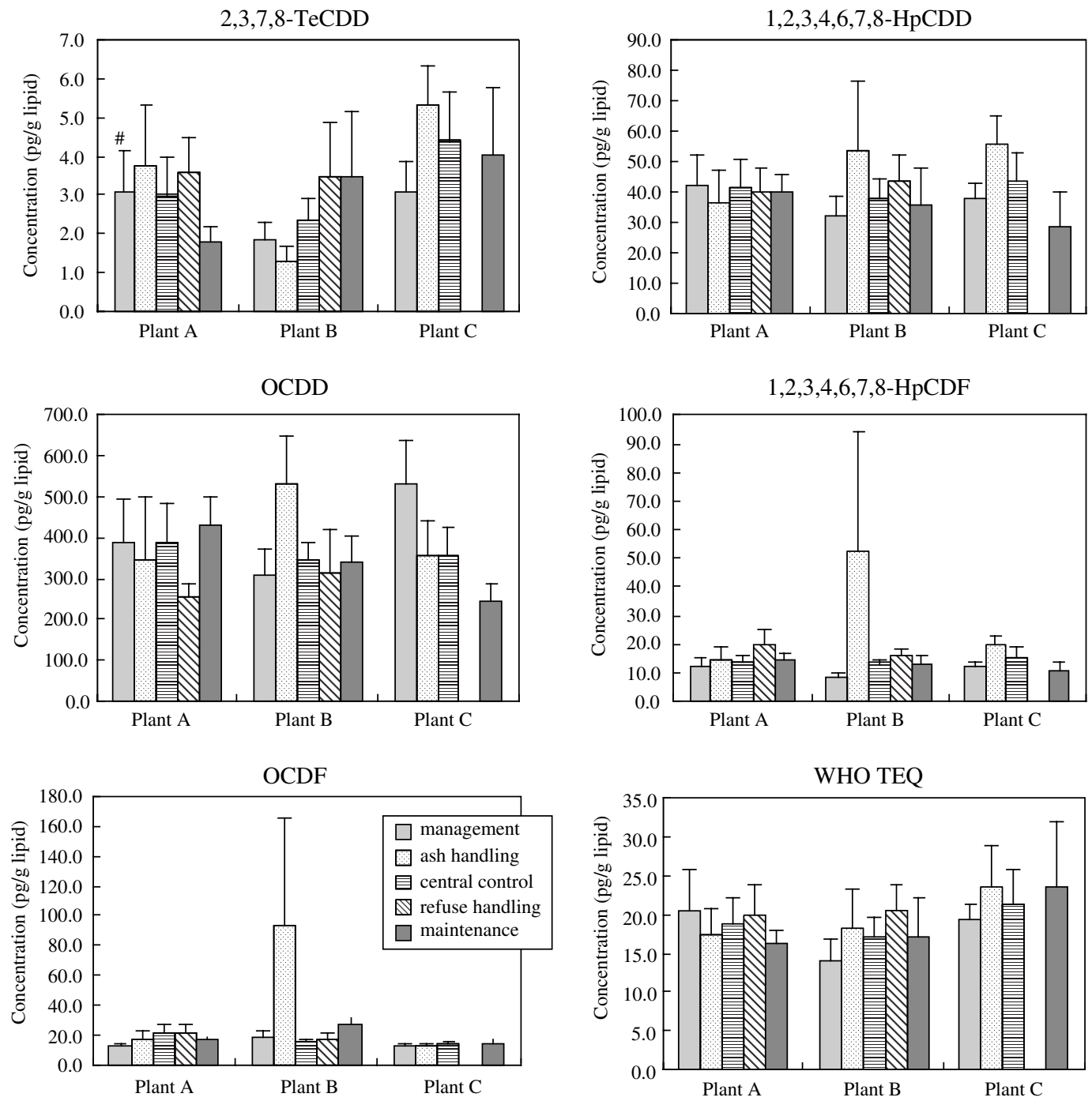

Fig. 2. Comparison of mean blood concentrations of specific congeners among five job groups in each of the three municipal waste incinerators. ${ }^{\#}$ Mean and error bar. All $p$-values were greater than 0.05 for the one-way analysis of variance comparing mean blood concentrations of respective congener among five job groups in each of the plants.

workers did not work in the places where air samples were collected. It could imply that our air PCDD/Fs data were not a good estimate for each worker's exposures to $\mathrm{PCDD} / \mathrm{Fs}$ in the plants. However, it would not necessarily invalidate the significant differences in air PCDD/ Fs levels among plants. Other potential reasons would include changes in occupational PCDD/Fs exposures in the three incineration plants over time and/or confounding effects by other unmeasured factors. Plant $\mathrm{A}$ has been remodeled and upgraded during February 1999-March 2001 to reduce the emissions of PCDD/Fs. Plant C underwent its $\mathrm{PCDD} /$ Fs emission control project between November 2000 and April 2002. The mean concentra- tions of PCDD/Fs in the flue gas were $3.10 \mathrm{ng}-\mathrm{TEQ} / \mathrm{N} \mathrm{m}^{3}$ (sampled in January 1999) and $0.038 \mathrm{ng}-\mathrm{TEQ} / \mathrm{N} \mathrm{m}^{3}$ (March 2001) in plant $\mathrm{A}, 0.042 \mathrm{ng}-\mathrm{TEQ} / \mathrm{N} \mathrm{m}^{3}$ (October 2000) and $0.06 \mathrm{ng}-\mathrm{TEQ} / \mathrm{N} \mathrm{m}^{3}$ (September 2001) in plant $\mathrm{B}$, and $4.8 \mathrm{ng}-\mathrm{TEQ} / \mathrm{N} \mathrm{m}^{3}$ (March 2000) and 0.2-0.3 ng$\mathrm{TEQ} / \mathrm{N} \mathrm{m}^{3}$ (August 2001) in plant $\mathrm{C}$ (data from the Taiwan Environmental Protection Agency). It is obvious that $\mathrm{PCDD} / \mathrm{Fs}$ emissions from plants $\mathrm{A}$ and $\mathrm{C}$ were dramatically reduced before the current air sampling. Moreover, the elimination of the 17 toxic $\mathrm{PCDD} / \mathrm{Fs}$ congeners in occupationally exposed persons has been found to differ greatly (Flesch-Janys et al., 1996). For example, the estimated median half-life was 7.2 years for 
2,3,7,8-TeCDD and 19.6 years for 2,3,4,7,8-PeCDF (Flesch-Janys et al., 1996). The variation in half-life of different congeners was not considered in this study. Furthermore, blood concentrations of PCDD/Fs reflect the exposure not only from workplace but also from other sources, mainly food consumption, which accounts for more than $95 \%$ of the daily intake of dioxins for the general population (Parzefall, 2002). According to a recent report of the first nationwide food sampling and dioxins measurement in Taiwan, the mean daily intake of PCDD/Fs from food in the Taiwanese male adult population was estimated to be $0.439(\mathrm{SD}=0.697) \mathrm{pg}$ WHO$\mathrm{TEQ} / \mathrm{kg}$ body weight/day (Taiwan Department of Health, 2002). Although the frequencies for milk consumption were significantly lower for plant A workers, inclusion of milk frequency in the multiple regression models did not affect our results. However, the intake of different foods as well as the contents of PCDD/Fs in the foods were not measured, and the workers' exposures to PCDD/Fs from food could not be evaluated in this study.

Only a few studies have measured the concentrations of PCDD/Fs in waste incineration plants. Bresnitz et al. (1992) reported air PCDD/Fs levels of 0-24.2 pg I-TEQ/ $\mathrm{m}^{3}$ in a municipal waste incinerator. Other studies measured PCDD/Fs in deposited dust (Kumagai et al., 2000; Kumagai et al., 2002) or in slag/ash (Schecter et al., 1995). In this study, the air PCDD/Fs levels in the three plants ranged from 0.06 to $7.11 \mathrm{pg} \mathrm{I}-\mathrm{TEQ} / \mathrm{m}^{3}$, which appeared to be within the range reported by Bresnitz et al. (1992).

Several studies have measured blood concentrations of $\mathrm{PCDD} / \mathrm{Fs}$ in incinerator workers. Schecter et al. (1991) reported a level of $21.9 \mathrm{pg}$ I-TEQ/g lipid in pooled blood from 56 workers. Two studies of German incinerator workers found concentrations of 24.3-66.1 pg I-TEQ/g lipid (Papke et al., 1993) and means of 34.3 $(\mathrm{SD}=11.6)$ and $39.7 \quad(\mathrm{SD}=11.9) \mathrm{pg} \quad \mathrm{I}-\mathrm{TEQ} / \mathrm{g}$ lipid (Schecter et al., 1995). Two studies in Japan found mean levels of 19.2-28.8 pg I-TEQ/g lipid in three groups of workers from three plants (Kumagai et al., 2000) and 22.8-30.7 pg I-TEQ/g lipid in workers from other three different plants (Kumagai et al., 2002). Domingo et al. (2001) reported a geometric mean of $24.4 \mathrm{pg} \mathrm{I}-\mathrm{TEQ} / \mathrm{g}$ lipid in 28 Spanish hazardous waste incinerator workers before operations of the incinerator, and Schuhmacher et al. (2002) reported a mean value of $16.9 \mathrm{pg} \mathrm{I-TEQ/g}$ lipid in plasma of 23 of the same workers one year after regular operations of the incinerator. Kitamura et al. (2000) reported a median PCDD/Fs concentration of 39 $\mathrm{pg}$ I-TEQ/g lipid in municipal waste incinerator workers. The geometric means of blood PCDD/Fs for workers from three plants in this study were 15.8, 14.6, and 19.1 pg WHO TEQ/g lipid, which were lower than levels reported in previous studies, except that the mean WHOTEQ of plant $\mathrm{C}$ workers was higher than that reported by Schuhmacher et al. (2002).

\section{Conclusions}

The three municipal waste incineration plants in Taiwan had average air PCDD/Fs concentrations between 0.08 and $3.01 \mathrm{pg} \mathrm{I-TEQ} / \mathrm{m}^{3}$. Workers from these plants had geometric mean blood PCDD/Fs levels of 14.6-19.1 pg WHO-TEQ/g lipid. Blood concentrations of 2,3,7,8TeCDD, 1,2,3,7,8-PeCDD, 2,3,7,8-TeCDF, 1,2,3,7,8PeCDF, 1,2,3,4,7,8,9-HpCDF, and OCDF, respectively, were significantly different among plants. The differences were not explained by the discrepancy in job contents, duration of employment and time activity among these plants.

\section{Acknowledgements}

This study was partially supported by a grant from the Environmental Protection Bureau of Taipei City, Taiwan.

\section{References}

Bresnitz, E.A., Roseman, J., Becker, D., Gracely, E., 1992. Morbidity among municipal waste incinerator workers. Am. J. Ind. Med. 22, 363-378.

Domingo, J.L., Schuhmacher, M., Agramunt, M.C., Müller, L., Neugebauer, F., 2001. Levels of metal and organic substances in blood and urine of workers at a new hazardous waste incinerator. Int. Arch. Occup. Environ. Health 74, 263-269.

Flesch-Janys, D., Becher, H., Gurn, P., Jung, D., Konietzko, J., Manz, A., Papke, O., 1996. Elimination of Polychlorinated dibenzo- $p$-dioxins and dibenzofurans in occupationally exposed persons. J. Toxicol. Environ. Health 47, 363-378.

Hornung, R.W., Reed, L.D., 1990. Estimation of average concentration in the presence of nondetectable values. Appl. Occup. Environ. Hyg. 5, 46-51.

Hu, S.W., Cheng, T.J., Chang-Chien, G.P., Chan, C.C., 2003. The association between dioxins/furans exposures and incinerator workers' hepatic function and blood lipids. J. Occup. Environ. Med. 45, 601-608.

Kim, Y., Yang, S.H., Kim, M., Shin, D.C., 2001. PCDD and PCDF exposures in workers and controls living near an industrial waste incinerator. Chemosphere 43, 985-987.

Kitamura, K., Kikuchi, Y., Watanabe, S., Waechter, G., Sakurai, H., Takada, T., 2000. Health effects of chronic exposure to polychlorinated dibenzo- $P$-dioxins (PCDD), dibenzofurans (PCDF) and coplanar PCB (Co-PCB) of municipal waste incinerator workers. J. Epidemiol. 10, 262270.

Kumagai, S., Koda, S., Miyakita, T., Yamaguchi, H., Katagi, K., Yasuda, N., 2000. Polychlorinated dibenzo-p-dioxin and dibenzofuran concentrations in the serum samples of workers at continuously burning municipal waste incinerators in Japan. Occup. Environ. Med. 57, 204-210.

Kumagai, S., Koda, S., Miyakita, T., Ueno, M., 2002. Polychlorinated dibenzo- $p$-dioxin and dibenzofuran concentrations in the serum samples of workers at intermittently 
burning municipal waste incinerators in Japan. Occup. Environ. Med. 59, 362-368.

McGregor, D.B., Partensky, C., Wilbourn, J., Rice, J.M., 1998. An IARC evaluation of polychlorinated dibenzo-p-dioxins and polychlorinated dibenzofurans as risk factors in human carcinogenesis. Environ. Health Perspect. 106 (Suppl. 2), 755-760.

Papke, O., Ball, M., Lis, A., 1993. Potential occupational exposure of municipal waste incinerator workers with PCDD/PCDF. Chemosphere 27, 203-209.

Parzefall, W., 2002. Risk assessment of dioxin contamination in human food. Food Chem. Toxicol. 40, 1185-1189.

Schecter, A.J., Malkin, R., Papke, O., Ball, M., Brandt-Rauf, P.W., 1991. Dioxin levels in blood of municipal incinerator workers. Med. Sci. Res. 19, 331-332.

Schecter, A., Papke, O., Ball, M., Lis, A., Brandt-Rauf, P., 1995. Dioxin concentrations in the blood of workers at municipal waste incinerators. Occup. Environ. Med. 52, 385-387.

Schuhmacher, M., Domingo, J.L., Agramunt, M.C., Bocio, A., Muller, L., 2002. Biological monitoring of metals and organic substances in hazardous-waste incineration workers. Int. Arch. Occup. Environ. Health 75, 500-506.

Taiwan Department of Health, 2002. Dioxins in Taiwan food and the estimated daily intake in Taiwanese [Chinese]. Taipei, Taiwan.

US EPA, 1994. Method 1613: Tetra-Through Octa-Chlorinated Dioxins and Furans by Isotope Dilution HRGC/HRMS. Revision B. EPA 821/B-94-005.

US EPA, 1999. Compendium Method TO-9A: Determination of Polychlorinated, Polybrominated and Brominated/Chlorinated Dibenzo- $p$-Dioxins and Dibenzofurans in Ambient Air. EPA/625/R-96/010b.

Van den Berg, M., Birnbaum, L.S., Bosveld, A.T.C., Brunström, B., Cook, P., Feeley, M., Giesy, J.P., Hanberg, A., Hasegawa, R., Kennedy, S.W., Kubiak, T., Larsen, J.C., Van Leeuwen, F.X.R., Liem, A.K.D., Nolt, C., Peterson, R.E., Poellinger, L., Safe, S.H., Schrenk, D., Tillit, D., Tysklind, M., Younes, M., Warn, F., Zacharewski, T., 1998. Toxic equivalency factors (TEFs) for PCBs, PCDDs, PCDFs for humans and wildlife. Environ. Health Perspect. 106, 775-792. 